Volume 13, Nomor 2, November 2021, pp 378-387 Copyright (C) 2017

Jurnal Akuntansi, Program Studi Akuntansi, Fakultas Bisnis, Universitas Kristen Maranatha. ISSN 2085-8698 | e-ISSN 2598-4977. http://journal.maranatha.edu

\title{
Persepsi Mahasiswa Akuntansi Terhadap Independensi Akuntan Publik: Studi Empirik pada Mahasiswa Akuntansi di Bandung
}

\author{
Trimanto Setyo Wardoyo 1 \\ Program Studi Akuntansi - Fakultas Bisnis - Univ. Kristen Maranatha \\ (Jl. Prof. drg. Surya Sumantri, M.P.H. No.65, Bandung, Jawa Barat) \\ trimantosetyowardoyo@yahoo.com \\ Tatik Budiningsih ${ }^{2}$ \\ Program Studi Manajemen - Fakultas Bisnis - Univ. Kristen Maranatha \\ (J1. Prof. drg. Surya Sumantri, M.P.H. No.65, Bandung, Jawa Barat) \\ tatikbudiningsih@gmail.com

\section{Herman Kambono ${ }^{3}$} \\ Program Studi Akuntansi - Fakultas Bisnis - Univ. Kristen Maranatha \\ (Jl. Prof. drg. Surya Sumantri, M.P.H. No.65, Bandung, Jawa Barat) \\ herman.kambono@yahoo.com \\ Elvira Veronica ${ }^{4}$ \\ Program Studi Akuntansi - Fakultas Bisnis - Univ. Kristen Maranatha \\ (Jl. Prof. drg. Surya Sumantri, M.P.H. No.65, Bandung, Jawa Barat) \\ viraroca@yahoo.co.id
}

\begin{abstract}
This study aims to determine the perceptions of accounting students towards the independence of public accountants in the city of Bandung. Positive perceptions indicate that the accounting profession, especially public accountants, has a proper place in accounting students. Through a questionnaire distributed with a sample of accounting students in the city of Bandung, with a target sample size of 60 students. From 137 respondents gathered, it can be seen based on the results of the analysis that students majoring in accounting in Bandung perceive that public accountants in Indonesia are not independent. In addition, the results of this study are expected to be inference for accounting students in Indonesia. The results of this study also show that there are differences in the perceptions of students majoring in accounting in Bandung who have never and who have taken auditing courses on the independence of public accountants in Indonesia.
\end{abstract}

Keywords: Perception, Independence, Accounting Profession, and Public Accountant 


\begin{abstract}
Abstrak
Penelitian ini bertujuan untuk mengetahui persepsi mahasiswa jurusan akuntansi terhadap independensi akuntan publik di kota Bandung. Persepsi yang positif mengindikasikan profesi akuntansi, khususnya akuntan publik memperoleh tempat yang layak pada mahasiswa jurusan akuntansi. Melalui kuesioner yang disebarkan dengan sampel mahasiswa jurusan akuntansi di kota Bandung, dengan target jumlah sampel 100 mahasiswa. Dari 127 responden yang terhimpun dapat diketahui berdasarkan hasil analisis bahwa mahasiswa jurusan akuntansi di Bandung mempersepsikan akuntan publik di Indonesia tidak independen. Selain itu hasil penelitian ini diharapkan bisa diinferensi untuk mahasiswa jurusan akuntansi di Indonesia. Hasil penelitian menyatakan bahwa terdapat perbedaan persepsi antara mahasiswa yang belum pernah dan yang sudah pernah menempuh mata kuliah auditing terhadap independensi akuntan publik di Indonesia.
\end{abstract}

\title{
Kata Kunci: Persepsi, Independensi, Profesi Akuntansi, dan Akuntan Publik
}

\section{Pendahuluan}

Profesi akuntansi bukan merupakan profesi yang tertua sebagaimana yang dikenal banyak orang namun keberadaanya kini terasa sangat penting, apalagi dihadapkan pada situasi yang volatilitasnya sangat besar dewasa ini. Dengan situasi yang ritme perubahannya cepat dan bahkan tidak terduga saat ini, setiap profesi harus mampu terus beradaptasi tanpa meninggalkan azasazas profesionalismenya. Khususnya akuntan publik yang bertugas melakukan audit atas laporan keuangan, selain harus memiliki pemahaman akuntansi, mereka juga harus memahami konsep dan praktik auditing. Tanpa memahami konsep dan praktik auditing, maka layanan jasa auditing yang mereka tawarkan tidak akan bernilai tinggi, dan berkemungkinan tidak akan dipercaya hasilnya oleh masyarakat. Jika ini terjadi, maka ini bagaikan lonceng kematian bagi profesi akuntansi. Standar auditing yang merupakan panduan praktikum akuntan publik mencakup tiga kelompok standar yang harus diterapkan dan ditegakkan dalam melaksanakan audit atas laporan keuangan, yaitu: standar umum, standar pekerjaan lapangan dan standar pelaporan. Standar umum secara ringkas mengatur tentang kompetensi, independensi dan kemahiran (kehati-hatian) profesional yang harus dipenuhi dalam audit atas laporan keuangan. Standar umum inilah yang pertama kali harus dipertimbangkan akuntan publik dalam menerima atau menolak suatu penugasan. Jika salah satu saja dari ketiga standar ini tidak dapat dipenuhi, maka akuntan publik yang bersangkutan secara etis tidak boleh menerima penugasan tersebut. Untuk itu jikalau akuntan publik tidak kompeten, tidak independen dan atau tidak bisa bertindak sesuai kemahiran profesionalnya, mereka harus menolak penugasan itu.

Peran utama akuntan publik adalah menjaga agar perniagaan tetap teratur di dalam perekonomian. Jika unsur independensi tidak tersentuh maka hasil akhir penugasan akuntan publik bisa jadi hanya menguntungkan salah satu kelompok dan merugikan kelompok lain. Hal ini akan berdampak tidak baik bagi dunia usaha, perniagaan maupun perekonomian secara keseluruhan. Di Indonesia jumlah CPA (Certified Public Accountant) sebanyak 4000 orang hal ini tentu masih sangat kurang dibandingkan dengan pesatnya pertumbuhan sektor usaha, oleh karena itu, Indonesia masih membutuhkan banyak akuntan publik profesional 
(antaranews.com). Menjadi sangat penting bagi profesi untuk mengetahui bagaimana persepsi berbagai pihak khususnya mahasiswa jurusan akuntansi terhadap independensi akuntan publik sehingga dari persepsi ini dapat menumbuhkan minat para mahasiswa untuk berkarir menjadi seorang akuntan publik profesional.

\section{Kerangka Teoritis dan Hipotesis}

\section{Teori Perilaku Terencana (Theory of Planned Behavior)}

Teori perilaku terencana merupakan teori yang menjelaskan tentang intensi seseorang untuk melakukan sesuatu. Intensi adalah niat seseorang untuk berperilaku. Sebelum melakukan sesuatu, seseorang akan memikirkan konsekuensi dari tindakannya. Intensi seseorang untuk berperilaku dipengaruhi oleh 3 faktor (Ajzen, 1991), yaitu: (1) sikap terhadap perilaku (attitude toward the behavior) yaitu sikap yang mengacu pada penilaian suatu tindakan apakah menimbulkan hal positif atau negatif; (2) norma subyektif (subjective norm) yaitu untuk melakukan suatu tindakan tertentu maka kita harus memastikan bahwa tindakan tersebut tidak melanggar norma yang ada; (3) Persepsi control perilaku (perceived behavioural control) yaitu persepsi mengenai kepemilikan keterampilan atau kesempatan untuk keberhasilan dalam melakukan tindakan (Tandiontong, 2016).

\section{Independensi Audit}

Dalam bidang audit, independensi dapat diartikan mengambil sudut pandang yang tidak bias (Arens dkk, 2017). Independensi juga dapat diartikan sebagai suatu sikap mental yang tidak bisa dipengaruhi, tidak dikendalikan, dan tidak bergantung pada pihak lain, independensi berarti adanya kejujuran dalam diri auditor dalam mempertimbangkan fakta dan adanya pertimbangan yang obyektif tidak memihak dalam diri auditor dalam merumuskan dan menyatakan pendapatnya (Mulyadi, 1992).
Aturan mengenai independensi tertuang di dalam SPAP (Standar Profesional Akuntan Publik, 2001-220), terdapat dua aspek independensi akuntan publik yaitu independensi dalam diri akuntan/ independence in fact yaitu kejujuran dalam diri akuntan dalam hal mempertimbangkan berbagai fakta yang dijumpainya dalam pemeriksaannya, dan independensi dalam penampilan/perceived independence atau independence in appearance yaitu independensi yang dipandang dari sudut pandangan pihak lain yang mengetahui informasi yang bersangkutan dengan diri akuntan.

Adapun faktor-faktor yang memengaruhi independensi menurut Arens (2017) adalah: (a) masalah kepentingan keuangan mencakup anggota, kepentingan keuangan langsung dan tidak langsung, material atau tidak, (b) masalah kepentingan keuangan yang terkait dengan isu-isu peminjaman yang normal, kepentingan keuangan pada hubungan keluarga, hubungan investor atau investee bersama dengan klien, dan komisaris, direksi, manajemen, atau pegawai perusahaan, (c) litigasi antara kantor akuntan publik dengan klien, (d) jasa pembukuan dan audit untuk klien yang sama dan (e) penugasan dan pembayaran imbal jasa audit oleh manajemen.

Terdapat tiga dari empat faktor yang diduga memengaruhi independensi (Shockley,1981) yaitu (a) jasa konsultasi manajemen yang diberikan KAP, (b) tingkat persaingan antar KAP dan (c) ukuran KAP. Adapun ikatan atau hubungan dengan klien tidak berpengaruh secara signifikan.

Supriyono dalam risetnya (1988) mengidentifikasi lima dari enam faktor yang diduga memengaruhi independensi akuntan publik yaitu: (a) ikatan kepentingan keuangan dan hubungan usaha dengan klien, (b) pemberian jasa lain selain jasa audit, (c) lamanya penugasan audit, (d) besarnya kantor akuntan publik, dan (e) besarnya fee audit, sedangkan persaingan antar kantor 
akuntan publik tidak berpengaruh. Nadirsyah (1993) menyimpulkan bahwa pemakai informasi akuntansi, akuntan, dan masyarakat umum secara signifikan tidak mempersepsikan akuntan publik independen.

Hasil penelitian Suyatmini (2002) tidak jauh berbeda dengan Supriyono, dan mengidentifikasi lima dari tujuh faktor yang mempengaruhi independensi auditor, yaitu: (a) ikatan kepentingan keuangan dan hubungan usaha dengan klien, (b) pemberian jasa lain selain jasa audit, (c) lamanya hubungan audit, (d) besarnya fee audit, dan (e) mempunyai hubungan sosial dengan klien, sedangkan persaingan antar kantor akuntan publik dan ukuran KAP tidak berpengaruh. Muswanto

(2004)

menyimpulkan bahwa akuntan pendidik dan mahasiswa akuntansi yang mempersepsikan independensi akuntan publik dapat dipengaruhi oleh ikatan kepentingan keuangan, lamanya hubungan usaha dan audit fee.

\section{Penelitian Soegiastuti} menunjukkan bahwa ada enam faktor yang berpengaruh negatif terhadap independensi dalam penampilan akuntan publik, yaitu (a) ikatan keuangan, (b) pemberian jasa lain selain jasa audit, (c) lamanya hubungan, (d) persaingan kantor akuntan publik, (e) pelayanan dari klien, dan (f) hubungan sosial. Namun, untuk ukuran kantor akuntan publik dan auditfee, berpengaruh positif.

Grasiela (2016) dalam penelitiannya menunjukkan bahwa mahasiswa akuntansi, mahasiswa non akuntansi, dan dosen Fakultas Ekonomi Universitas Kristen Maranatha mempersepsikan independensi akuntan publik dengan baik, dengan urutan sebagai berikut: dosen Fakultas Ekonomi paling tinggi mempersepsikan independensi akuntan publik, disusul mahasiswa akuntansi, baru selanjutnya mahasiswa non akuntansi. Namun terdapat perbedaan yang signifikan antara persepsi mahasiswa akuntansi, mahasiswa non akuntansi dan dosen Fakultas Ekonomi mengenai independensi akuntan publik. Hal ini dapat disebabkan karena perbedaan status mahasiswa dengan dosen, serta perbedaan jurusan akuntansi serta non-akuntansi yang menyebabkan pemahaman yang berbeda mengenai independensi akuntan publik.

Herlin \& M. Sari (2018) dalam risetnya dengan responden mahasiswa University of Bengkulu Dehasen menemukan yang paling dominan memengaruhi independensi adalah pengakuan profesional dan kepribadian.

Kamath, dkk (2018) dengan metode eksperimen menemukan bahwa peserta menilai kompetensi dan independensi auditor (khususnya perhatian terhadap detail, upaya, dan sikap skeptis) menjadi lebih tinggi ketika biaya meningkat daripada menurun secara signifikan pada saat rotasi, dan mereka menilai kompetensi auditor menjadi lebih tinggi ketika rotasi ditujukan spesialis industri daripada spesialis non industri. Temuan ini berlaku terlepas dari apakah rotasi berada di tingkat kantor akuntan atau partner.

Pakambi, dkk (2018) menemukan bahwa terdapat perbedaan persepsi mengenai tanggung jawab auditor antara mahasiswa akuntansi dan mahasiswa manajemen. Selain itu, ditemukan juga perbedaan persepsi mengenai independensi auditor di kalangan mahasiswa akuntansi dan mahasiswa manajemen

Laksmi \& Hafis (2019) menemukan bahwa penghargaan finansial, pengakuan profesional, pasar tenaga kerja pertimbangan dan pelatihan profesional secara positif mempengaruhi minat mahasiswa akuntansi untuk menjadi akuntan publik. Hasil penelitian juga menunjukkan bahwa lingkungan kerja, nilai-nilai sosial dan kepribadian tidak berpengaruh terhadap minat mahasiswa akuntansi menjadi akuntan publik.

Atas dasar bahasan teori serta ilustrasi hasil riset terkini, maka peneliti sampai pada hipotesis sebagai berikut:

HI : Mahasiswa jurusan akuntansi di Bandung mempersepsikan akuntan publik di Indonesia tidak independen. 
$\mathrm{H} 2$ : Terdapat perbedaan persepsi antara mahasiswa jurusan akuntasi di Bandung yang sudah menempuh dan lulus mata kuliah auditing dengan mahasiswa jurusan akuntansi yang belum menempuh mata kuliah auditing.

\section{Metode Penelitian}

Penelitian ini adalah murni merupakan penelitian lapangan (field study), karena untuk memperoleh data dari responden peneliti melakukan penelitian langsung ke lapangan. Data yang dihimpun dilakukan melalui survei, yaitu menggunakan perangkat (instrumen) kuesioner untuk dibagikan dan diharap dapat dijawab langsung oleh responden. Karena peneliti tidak bisa memengaruhi variabel yang diteliti, maka penelitian ini bersifat ex post facto, data diambil didasarkan atas apa yang sudah atau sedang terjadi/dialami pada diri responden. Analisis data dan kesimpulan hasil menggunakan statistik, tetapi analisis kualitatif dan deskriptif tetap digunakan untuk memperkaya hasil dan makna penelitian ini.

\section{Metode Pengumpulan Data}

Data untuk riset ini dihimpun dengan metode survei dengan menggunakan kuesioner sebagai instrumen untuk pengumpulannya. Jadi instrumen ini berfungsi ganda, yaitu sebagai alat mengumpulkan data tetapi sekaligus sebagai alat mengukur data. Sesuai dengan target responden adalah mahasiswa, maka data dihimpun saat mahasiswa hadir di kampus untuk kuliah. Diharapkan kuesioner dapat diisi dalam 10-15 menit. Peneliti atau interviewer dapat memberi penjelasan singkat kepada mahasiswa sebagai target responden tersebut jika diperlukan. Untuk menghindari banyak pertanyaan maka kuesioner juga dirancang dengan bahasa yang sederhana dan dapat dimengerti.

\section{Populasi dan Sampel Penelitian}

Populasi adalah total himpunan dari elemen untuk mana kita akan membuat inferensi.
Untuk penelitian ini yang dimaksud dengan mahasiswa akuntansi adalah mahasiswa yang kuliah pada program Strata-1 jurusan akuntansi di perguruan tinggi swasta di Bandung yang berakreditasi A. Untuk itu yang menjadi populasi penelitian ini adalah total mahasiswa jurusan akuntansi pada pada program Strata-1 perguruan tinggi swasta di Bandung yang berakreditasi A.

Rancangan peneliti sampel akan diambil dari lima universitas yaitu Universitas Kristen Maranatha, Universitas Telkom Bandung, Universitas Widyatama, Universitas Jendral Ahmad Yani, dan STIE Ekuitas. Pemilihan kelima universitas tersebut didasarkan pada kemudahannya serta masing-masing jurusan akuntansi terakreditasi A. Selain itu secara keseluruhan karakteristik mahasiswa masing-masing perguruan tinggi berbeda, sehingga sampel diambil dari latar belakang yang sesungguhnya variatif (dari sisi lingkungan kampus).

Jumlah mahasiswa aktif jurusan Akuntansi Universitas Telkom per tahun akademik 2020/2021 sebanyak 1463 mahasiswa, sedangkan jumlah mahasiswa aktif jurusan akuntansi Universitas Widyatama per Ganjil 2020/2021 301 mahasiswa. Jumlah mahasiswa aktif jurusan akuntansi Universitas Jenderal Ahmad Yani per tahun akademik 2020/2021 1143 orang, jumlah mahasiswa akuntansi di Universitas Kristen Maranatha 458 mahasiswa, dan jumlah mahasiswa akuntansi di STIE Ekuitas sebanyak 1476 mahasiswa. Dari informasi tersebut, total populasi dari kelima universitas adalah 4.841 kemudian menggunakan rumus slovin dengan tingkat eror $10 \%$ sehingga diperoleh minimal sampel 100 orang.

\section{Operasionalisasi Variabel}

Variabel penelitian ini adalah persepsi mahasiswa dengan indikator variabel adalah respons subyek atau responden terhadap persepsi mahasiswa jurusan akuntansi di Bandung terhadap independensi akuntan publik di Indonesia. Adapun faktor-faktor 
yang memengaruhi independensi tersebut disajikan pada Tabel 1 berikut ini.

\section{Tabel 1}

Variabel, Indikator, dan Skala Pengukuran

\begin{tabular}{|c|c|c|c|}
\hline Variabel & Indikator & Sub Indikator & \begin{tabular}{|c|} 
Skala \\
pengukuran
\end{tabular} \\
\hline $\begin{array}{l}\text { Persepsi } \\
\text { mahasiswa }\end{array}$ & $\begin{array}{l}\text { Respons terhadap } \\
\text { situsi yang dihadapi, } \\
\text { tercermin dari hasil } \\
\text { isian kuesioner }\end{array}$ & & Ordinal \\
\hline \multirow[t]{5}{*}{$\begin{array}{l}\text { Independensi } \\
\text { akuntan publik }\end{array}$} & $\begin{array}{l}\text { 1. Kepentingan } \\
\text { keuangan }\end{array}$ & $\begin{array}{l}\text { a. Anggota yang tercakup } \\
\text { b. Kepentingan langsung } \\
\text { dan tidak langsung } \\
\text { c. Material atau tidak } \\
\text { material }\end{array}$ & Ordinal \\
\hline & $\begin{array}{l}\text { 2. Masalah } \\
\text { kepentingan } \\
\text { keuangan terkait }\end{array}$ & $\begin{array}{l}\text { a. Prosedur peminjaman } \\
\text { yang normal } \\
\text { b. Kepentingan keuangan } \\
\text { pada hubungan } \\
\text { keluarga } \\
\text { c. Hubungan investor atau } \\
\text { imvestee bersama } \\
\text { dengan klien. } \\
\text { d. Komisaris, direksi, } \\
\text { manajemen, atau } \\
\text { pegawai perusahaan }\end{array}$ & Ordinal \\
\hline & $\begin{array}{lr}\text { 3. Litigasi } & \text { antara } \\
\text { kantor } & \text { akuntan } \\
\text { publik } & \text { dengan } \\
\text { klien } & \\
\end{array}$ & & Ordinal \\
\hline & $\begin{array}{l}\text { 4. Jasa pembukuan } \\
\text { dan audit untuk } \\
\text { klien yang sama }\end{array}$ & & Ordinal \\
\hline & $\begin{array}{lr}\text { 5.Penugasan } & \text { dan } \\
\text { pembayaran imbal } \\
\text { asa audit oleh } \\
\text { manajemen }\end{array}$ & & Ordinal \\
\hline
\end{tabular}

\section{Teknik Analisis Data dan Pengujian Hipotesis}

Pada penelitian ini, pengumpulan data dengan penyebaran kuesioner, oleh karena itu diperlukan dua macam uji kuesioner yaitu uji validitas dan uji reliabilitas.

Uji validitas bertujuan untuk mengetahui tepat atau tidaknya kuesioner/angket. Dalam penelitian ini akan digunakan uji korelasi Pearson Product Moment.

Uji reliabilitas menyangkut ketepatan alat ukur. Instrumen yang reliabel adalah instrumen yang bila digunakan beberapa kali untuk mengukur obyek yang sama akan menghasilkan data yang sama. Ide pokok dalam konsep reliabilitas adalah sejauh mana hasil pengukuran dapat dipercaya, artinya sejauh mana hasil pengukuran terbebas dari kesalahan pengukuran. Uji reliabilitas dilakukan dengan uji Cronbach Alpha.

\section{Pengujian Hipotesis}

Penelitian ini mencoba menguji dua hipotesis yaitu:
Hipotesis 1 (H1) : Mahasiswa jurusan akuntansi di Bandung mempersepsikan akuntan publik di Indonesia tidak independen.

Hipotesis 2 (H2): Terdapat perbedaan persepsi antara mahasiswa jurusan akuntasi di Bandung yang yang memiliki IPK $\leq 3.00$ dengan yang memiliki IPK $>$ 3.00 .

Untuk menguji $\mathrm{H} 1$, dilakukan prosedur sebagai berikut:

a. Menghitung rerata riil skor jawaban responden, yaitu jumlah skor jawaban dibagi jumlah responden.

b. Menentukan rerata harapan. Dalam penelitian ini rerata harapan adalah $=3$

c. Jika rerata riil lebih dari atau sama dengan rerata harapan, berarti responden mempunyai persepsi bahwa faktor-faktor tersebut dipertimbangkan nasabah, yang berarti $\mathrm{H} 1$ diterima.

Untuk menguji H2, dilakukan prosedur sebagai berikut:

a. Menghitung rerata skor untuk setiap kelompok mahasiswa yang sudah menempuh dan lulus mata kuliah auditing dengan mahasiswa yang belum lulus atau belum menempuh mata kuliah auditing.

b. Menentukan perbedaan rerata skor kedua kelompok dengan menggunakan uji $\mathrm{F}$ (anova satu jalur)

c. Dengan tingkat signifikansi $(\alpha)=0.10$, dapat ditentukan apakah kedua skor rerata tersebut secara statistik berbeda.

d. Karena pengujian menggunakan komputer maka penerimaan atau penolakan hipotesis cukup hanya melihat peluang ralat (prob. value $=\mathrm{p}$ ), dengan kriteria sebagai berikut:

Hipotesis diterima jika nilai p-nya $>0.10$. Hipotesis ditolak jika nilai p-nya $\leq 0.10$.

\section{Teknik Pengembangan Instrumen}

Instrumen yang dimaksud di sini adalah kuesioner yang merupakan alat utama dalam pengumpulan data. Peneliti mengembangkan kuesioner untuk memenuhi tujuan riset yang telah dirumuskan pada Bab I. Secara umum kuesioner terdiri dari tiga bagian, yaitu: 
(a) demografi responden, (b) target data, dan

(c) komentar responden. Responden hanya cukup menuliskan tanda silang (X) pada kotak yang tersedia sesuai pilihannya. Jawaban atas pertanyaan/pernyataan pada bagian ini semua berskala ordinal, dengan skor dari 1 sampai dengan 5. Adapun pilihan jawaban tersebut terdiri dari:

$5=$ Sangat Setuju (SS)

$4=$ Setuju (S)

$3=$ Tidak Tahu/Ragu-Ragu/Netral(TT/RR/N)

$2=$ Tidak Setuju (TS)

$1=$ Sangat Tidak Setuju (STS)

\section{Hasil Penelitian dan Pembahasan}

Berdasarkan rencana awal untuk memperoleh responden sebanyak 100 orang mahasiswa, ternyata peneliti berhasil memperoleh jumlah lebih besar dari yang direncanakan tersebut. Total jumlah responden yang dapat diperoleh dalam usaha pengumpulan data adalah sebanyak 127 orang, yang berasal dari 5 perguruan tinggi di Bandung yang prodi akuntansinya berakreditasi A. Tabel 2 me-resume data responden.

Tabel 2

\section{Resume Data Responden}

\begin{tabular}{|c|c|c|c|c|c|c|c|c|c|}
\hline \multirow[b]{2}{*}{ No } & \multirow{2}{*}{$\begin{array}{c}\text { Nama } \\
\text { Perguutuan } \\
\text { Tinggi }\end{array}$} & \multicolumn{2}{|c|}{ Jenis Kelamin } & \multicolumn{2}{|c|}{ IPK } & \multicolumn{2}{|c|}{$\begin{array}{l}\text { Belum/pernahh } \\
\text { kuliah auditing }\end{array}$} & \multicolumn{2}{|c|}{$\begin{array}{c}\text { Jumlahh } \\
\text { tesponden }\end{array}$} \\
\hline & & Pria & Wanita & $\begin{array}{c}< \\
3.00\end{array}$ & $\begin{array}{l}\geq \\
3.00\end{array}$ & Belum & Pernah & Jumblas & $\%$ \\
\hline 1 & $\begin{array}{l}\text { Universitas } \\
\text { Kristen } \\
\text { Maranatha }\end{array}$ & 9 & 19 & 3 & 25 & 11 & 17 & 28 & 22.05 \\
\hline 2 & $\begin{array}{l}\text { Telkom } \\
\text { University }\end{array}$ & 5 & 18 & 1 & 22 & 2 & 21 & 23 & 18.11 \\
\hline 4 & $\begin{array}{l}\text { Universitas } \\
\text { Widvatama }\end{array}$ & 6 & 23 & 2 & 27 & 24 & 5 & 29 & 22.83 \\
\hline 5 & $\begin{array}{c}\text { Universitas } \\
\text { Jendral Achbad } \\
\text { Yani }\end{array}$ & 1 & 18 & 5 & 14 & 8 & 11 & 19 & 14.96 \\
\hline 6 & STIE Ekuitas & 5 & 23 & 2 & 26 & 1 & 27 & 28 & 22.05 \\
\hline & Jumlah & 26 & 101 & 13 & 114 & 47 & 80 & 127 & 100 \\
\hline & Perssentase & 20.4 & 79.53 & 10.2 & 89.7 & 37.01 & 66.99 & 100 & \\
\hline
\end{tabular}

\section{Pengujian Instrumen}

Uji validitas dilakukan dan dari 30 butir pernyataan terdapat tiga butir pernyataan yang tidak valid karena $\mathrm{R}$ Hitung lebih dari $\mathrm{R}$ Tabel sebesar 0.1743. Ketiga butir pernyataan itu adalah butir 23 dengan $\mathrm{R}$ Hitung 0.156 , butir 25 dengan R Hitung 0.126 dan butir 30 dengan R Hitung 0.138 .
Ketiga butir pernyataan ini dibuang dan tidak disertakan lagi dalam analisis selanjutnya.

Selanjutnya uji reliabilitas dilakukan dan hasilnya dapat dilihat pada Tabel 2. Total dari 27 butir pernyatan yang dilakukan prngujian tersebut menghasilkan angka alpha sebesar 0.917, yang mengindikasikan bahwa reliabilitas instrumen ini tinggi.

Tabel 3

Hasil Pengujian Reliabilitas Case Processing Summary

\begin{tabular}{|ll|c|c|}
\hline & & $\mathrm{N}$ & $\%$ \\
\hline \multirow{4}{*}{ Cases } & Valid $^{2}$ & 127 & 100.0 \\
& Excluded $^{\mathrm{a}}$ & 0 & .0 \\
& Total & 127 & 100.0 \\
\hline
\end{tabular}

a. Listwise deletion based on all variables in the procedure.

\section{Reliability Statistics}

\begin{tabular}{|c|c|}
\hline Cronbach's Alpha & N of Items \\
\hline .917 & 27 \\
\hline
\end{tabular}

\section{Pengujian Hipotesis}

Hipotesis 1 (H1) : Mahasiswa jurusan akuntansi di Bandung mempersepsikan akuntan publik di Indonesia tidak independen.

Untuk menguji H1, dilakukan prosedur sebagai berikut:

a. Menghitung rerata riil skor jawaban responden, yaitu jumlah skor jawaban dibagi jumlah responden.

b. Menentukan rerata harapan. Dalam penelitian ini rerata harapan adalah $=3$

c. Jika rerata riil kurang dari atau sama dengan rerata harapan, berarti responden mempunyai persepsi bahwa akuntan publik di Indonesia tidak independen.

Berdasarkan hasil pengolahan data melalui tes nonparametrik, yaitu One-Sample Test yang dapat dilihat pada Tabel 3 dapat diketahui bahwa rerata skor untuk semua butir pernyataan adalah sebesar 2.6854, dengan tingkat signifikansi 0.00 . 
Tabel 4 Output One-Sample Test

\begin{tabular}{|l|c|c|c|c|}
\hline & $\mathrm{N}$ & Mean & Std. Deviation & $\begin{array}{c}\text { Std. Error } \\
\text { Mean }\end{array}$ \\
\hline Rerata Aktual & 127 & 2.6854 & .53542 & .04751 \\
\hline
\end{tabular}

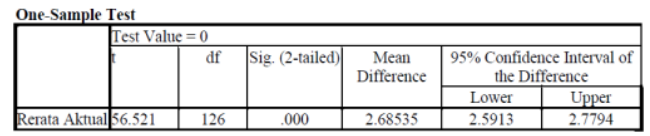

Angka ini lebih kecil dari 3.00, sehingga berdasarkan kriteria yang telah ditetapkan maka hasil ini menunjukkan bahwa mahasiswa jurusan akuntansi di Bandung mempersepsikan akuntan publik di Indoneia tidak independen. Dengan demikian Hipotesis 1 (H1) yang menyatakan bahwa Mahasiswa jurusan akuntansi di Bandung mempersepsikan akuntan publik di Indonesia tidak independen, dapat diterima.

Hipotesis 2 (H2): Terdapat perbedaan persepsi antara mahasiswa jurusan akuntansi di Bandung yang sudah menempuh dan lulus mata kuliah auditing dengan mahasiswa jurusan akuntansi yang belum menempuh atau belum lulus mata kuliah auditing.

Untuk menguji $\mathrm{H} 2$, dilakukan prosedur sebagai berikut:

a. Menghitung rerata skor untuk setiap kelompok mahasiswa yang sudah menempuh dan lulus mata kuliah auditing dengan mahasiswa yang belum lulus atau belum menempuh mata kuliah auditing.

b. Menentukan perbedaan rerata skor kedua kelompok dengan menggunakan uji $\mathrm{F}$ (anova satu jalur)

c. Dengan tingkat signifikansi $(\alpha)=0.10$, dapat ditentukan apakah kedua skor rerata tersebut secara statistik berbeda.

d. Karena pengujian menggunakan komputer maka penerimaan atau penolakan hipotesis cukup hanya melihat peluang ralat (prob. value $=\mathrm{p}$ ),

dengan kriteria sebagai berikut:

Hipotesis diterima jika nilai p-nya $>0.10$. Hipotesis ditolak jika nilai $\mathrm{p}$-nya $\leq 0.10$
Pengujian hipotesis ini dilakukan melalui uji independent sample t test dengan SPSS. Hasil pengujian dapat dilihat pada Tabel 4. Berdasarkan output tersebut diketahui nilai sig levene's test for equality of variance adalah sebesar 0.001 maka dapat diartikan bahwa varians data antara dua kelompok heterogen atau berbeda sehingga penafsiran tabel output independen sample $t$ test berpedoman pada nilai yang terdapat pada tabel 'equal variances not assumed'. Berdasarkan tabel output 'equal varinces not assumed' pada bagian sig (2-tailed) sebesar $0,014<0,10$ maka dapat disimpulkan bahwa terdapat perbedaan yang signifikan antara rerata kelompok mahasiswa yang sudah pernah mengikuti mata kuliah auditing dengan kelompok mahasiswa yang belum pernah mengikuti mata kuliah auditing. Ini bearati bahwa terdapat perbedaan yang signifikan persepsi mahasiswa dalam dua kelompok tersebut.

\section{Tabel 5}

Output Uji Independent Sampel t Test

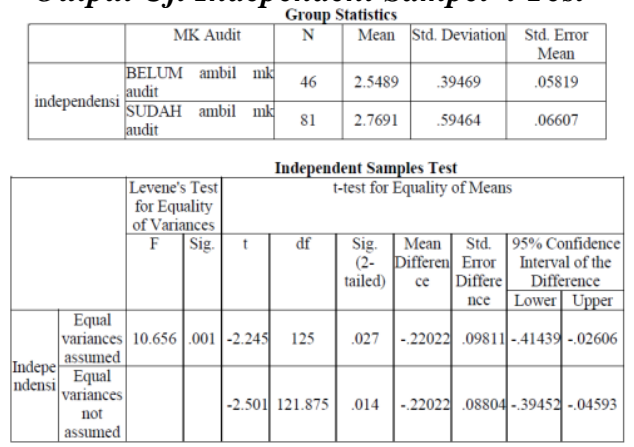

Temuan ini menunjukkan pengetahuan auditing pada rata-ratanya telah telah dapat mengubah persepsi mahasiswa terhadap independensi akuntan publik yang telah dimiliki sebelum mengikuti mata kuliah tersebut. Ini juga membuktikan bahwa bertambahnya ilmu pengetahuan dapat mengubah persepsi seseorang terhadap sesuatu. Dengan demikian pelajaran auditing secara nyata telah berkontribusi dalam mengubah persepsi mahasiswa terhadap independensi akuntan publik di Indonesia. 
Persepsi mahasiswa terhadap independensi akuntan publik secara proporsional akan menjadi sumbangan berharga bagi profesi akuntansi khususnya akuntan publik di Indonesia.

Perlu dilakukan riset yang lebih luas terhadap topik ini sehingga bisa menjangkau mahasiswa di Indonesia Selain itu perlu kajian apakah terdapat variasi persepsi mahasiswa dari perguruan tinggi dengan akreditasi yang sama di Indonesia.

\section{Simpulan dan Saran}

\section{Simpulan}

Atas dasar bahasan pada bab sebelumnya dapat diambil kesimpulan bahwa mahasiswa jurusan akutansi di Bandung mempersepsikan akuntan publik di Indonesia tidak independen. Selain itu terdapat perbedaan persepsi antara mahasiswa jurusan akuntasi di Bandung yang sudah menempuh dan lulus mata kuliah auditing dengan mahasiswa jurusan akuntansi yang belum menempuh kuliah auditing. Temuan penting dari riset ini adalah bahwa pelajaran auditing secara nyata telah berkontribusi dalam mengubah persepsi mahasiswa terhadap independensi akuntan publik di Indonesia.

\section{Saran}

Saran yang diberikan terkait implikasinya pada riset ini adalah sebaiknya perlu dilakukan riset yang lebih luas terhadap topik ini sehingga bisa menjangkau mahasiswa di Indonesia. Selain itu perlu kajian apakah terdapat variasi persepsi mahasiswa dari perguruan tinggi dengan akreditasi yang sama di Indonesia.

\section{Daftar Pustaka}

Accounting Principles Board Statement No. 4. (1970)..Basic Concepts and Accounting Principels Underlying Financial Statements of Business Enterprices. New York: AICPA.
Agnes Grasiela (2016). Persepsi mahasiswa akuntansi, mahasiswa nonakuntans dan dosen Fakulutas Ekonomi Universitas Kristen Maranatha terhadap independensi akuntan publik. Tugas Akhir. Bandung: Program Studi Akuntansi FE UKM.

Ayu Chairina Laksmi \& Savero Izkha Al Hafis. (2019). The influence of accounting students' perception of public accounting profession: A study from Indonesia. Journal of Contemporary Accounting, Volume 1, Issue 1, 2019, 4763

Arens, Alvin A., Randal J. Elder, Mark S. Beasly \& Chris E. Hogan (2017). Auditing and Assurance Services. Sixteenth Edition. Harlow England: Pearson Education@2017.

Chaplin, J. P. (2008). Kamus Psikologi Lengkap. Jakarta: PT Raja Grafindo

Herlin, H., \& M. Sari (2018). Persepsi Mahasiswa Akuntansi Terhadap Profesi Akuntan Publik. Agregat: Jurnal Ekonomi dan Bisnis, 2(2), 366-376.

Ikatan Akuntan Indonesia (2001). Standar Profesional Akuntan Publik. Yogyakarta: PT Salemba Empat Patria.

Janti Soegiastuti (2015). Persepsi masyarakat tentang Independensi auditor dalam penampilan (studi empiris pada analis kredit badan kredit kecamatan di wilayah Jawa Tengah). Serat

Acitya - Jurnal Ilmiah. Semarang: UNTAG

Mulyadi (2002). Auditing. Edisi 6. Yogyakarta: PT Salemba Empat Patria.

Muswanto, Herry Sabda. (2004). Persepsi Akuntan Pendidik dan Mahasiswa Akuntansi terhadap Independensi Penampilan Akuntan Publik. Skripsi. Surakarta: Universitas Sebelas Maret.

Nadirsyah (1993). Persepsi pemakai informasi akuntansi, akuntan, dan masyarakat umum terhadap independensi akuntan publik. Tesis. Yogyakarta: Program Magister Sains Akuntansi Univeersitas Gadjah Mada.

Roger Kamath, Ting-Chiao Huang, adan Robyn A. Moroney. (2018). Auditor Rotation and Perceived Competence and 
Independence: The Effect of Fees and Industry Specialization. Journal of International Journal of International Research: Fall, Vol. 17, No. 3, pp. 153175.

Sarwono, Sarlito. (2009). Pengantar Psikologi Umum. Jakarta: Rajawali Press.

Shaleh, Abdul Rahman. (2009). Psikologi Suatu Pengantar dalam Perspektif Islam.

Shockley, Randolph A. (1981). Perceptions of Auditors Independence: An Imprical Analysis.The Accounting Review. vol LVI, no.4, pp. 785-800.

Siska Cantika Pakambi, Inggriani Elim, dan Sintje Rondonuwu. (2018). Analisa persepsi mahasiswa terhadap pelaksanaan audit pada opini WTP dalam kaitannya dengan tanggung jawab dan independensi auditor. Jurnal Riset Akuntansi Going Concern 13(2), 2018, 109-118.

Supriyono. (1988). Pemeriksaan Akuntan: Faktor-faktor yang memengaruhi independensi akuntan publik, suatu hasil penilitian empiris di Indonesia. Yogyakarta: BPFE.

Suyatmini (2002). Studi empiris faktorfaktor yang mempengaruhi independensi penampilan akuntan publik. Penelitian untuk Tesis. Semarang: Program Magister Akuntansi Universitas Diponegoro.

Tandiontong, M. (2016). Kualitas Audit dan Pengukurannya. Bandung: Alfabeta.

https://www.antaranews.com/berita/791557/ indonesia-butuh-lebih-banyak-akuntanpublik). 